\title{
Molecular diagnosis of SARS-CoV-2 in seminal fluid
}

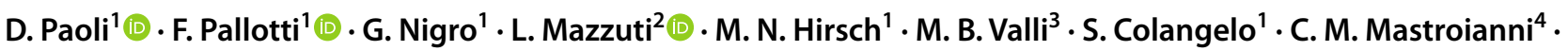

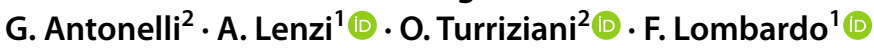

Received: 18 March 2021 / Accepted: 17 April 2021 / Published online: 30 April 2021

(C) The Author(s) 2021

\begin{abstract}
Purpose Due to relevant repercussions on reproductive medicine, we aimed to evaluate feasibility of RT-PCR as a detection method of SARS-CoV-2 RNA in seminal fluid.

Methods A qualitative determination of the RT-PCR assays in semen was performed through different approaches: (1) efficiency of RNA extraction from sperm and seminal plasma was determined using PRM1 and PRM2 mRNA and a heterologous system as control; (2) samples obtained by diluting viral preparation from a SARS-CoV-2 panel (virus cultured in Vero E6 cell lines) were tested; (3) viral presence in different fractions of seminal fluid (whole sample, seminal plasma and post-centrifugation pellet) was evaluated. Semen samples from mild and recovered COVID-19 subjects were collected by patients referring to the Infectious Disease Department of the Policlinico Umberto I Hospital - "Sapienza" University of Rome. Control subjects were recruited at the Laboratory of Seminology-Sperm Bank "Loredana Gandini" of the same hospital.

Results The control panel using viral preparations diluted in saline and seminal fluid showed the capability to detect viral RNA presence with $C_{\mathrm{t}}$ values depending on the initial viral concentration. All tested semen samples were negative for SARSCoV-2, regardless of the nasopharyngeal swab result or seminal fluid fraction.

Conclusion These preliminary data show that RT-PCR for SARS-CoV-2 RNA testing appears to be a feasible method for the molecular diagnosis of SARS-CoV-2 in seminal fluid, supported by results of the control panel. The ability to detect SARS-CoV-2 in semen is extremely important for reproductive medicine, especially in assisted reproductive technology and sperm cryopreservation.
\end{abstract}

Keywords SARS-CoV-2 $\cdot$ COVID-19 $\cdot$ RT-PCR $\cdot$ Seminal fluid

\section{Introduction}

Coronaviruses are a family of positive-sense singlestranded RNA viruses that cause infections in birds and mammals as well as humans, inducing respiratory, hepatic, neurological and gastrointestinal diseases [1]. The novel coronavirus SARS-CoV-2 causes pneumonia, a severe acute respiratory disease (COVID-19). Structurally, SARS-CoV-2 is composed of several proteins: nucleocapsid $(\mathrm{N})$, spike (S), membrane (M) and envelope (E). The spike protein is particularly important, as it enables the

D. Paoli and F. Pallotti contributed equally.

D. Paoli

donatella.paoli@uniroma1.it

Extended author information available on the last page of the article virus to enter and infect host cells and determines viral pathogenesis, host tropism, and disease [2].

The use of accurate molecular tests has enabled the presence and development of this virus to be monitored. The gold standard for the diagnosis of SARS-CoV-2 infection is qualitative reverse transcription-polymerase chain reaction (qRT-PCR) testing of nasopharyngeal swabs $[2$, 3]. The usual SARS-CoV-2 gene targets are E, S, N1, $\mathrm{N} 2$, and RpRd. The RT-PCR cycle threshold $\left(C_{\mathrm{t}}\right)$ value is an indicator of the number of viral copies, with lower $C_{\mathrm{t}}$ values corresponding to higher viral copy numbers. A $C_{\mathrm{t}}$ less than 40 is interpreted as positive for SARS-CoV-2 RNA [4]. However, it must be pointed out that $C_{\mathrm{t}}$ values are not standardized to enable quantification of the viral concentration.

Recently, some authors observed that the N2 gene may be prone to false positive results. Particularly high 
$C_{\mathrm{t}}$ values ( $\left.>40\right)$ have been detected in nasopharyngeal swabs using N2 as the RT-PCR target, suggesting either "very low" viral load or "false positive" results. Careful interpretation of the clinical relevance of this "very low" test result is currently needed [4]. Although respiratory samples are the reference specimens, the virus has been found in numerous human samples, including urine, feces, cerebrospinal fluid, lacrimal fluid and blood [5]. In several studies, bronchoalveolar lavage fluid (BLF) (93\%), sputum (72\%) pharyngeal swabs (32\%), feces (29\%), and blood (1\%) samples have tested positive. None of the urine samples tested were positive $[4,6]$. According to some authors, these different viral loads could be attributed to the sample type or timing, the stage of the disease and/or where the specimen was taken from, all factors that play an important role in RT-qPCR results [7].

Negative test results do not necessarily rule out infection. False negatives can occur in preanalytical steps (poor specimen collection, inappropriate sampling), analytical steps (PCR inhibition, target mutation or low viral load in the sample), and postanalytical steps (transcription error) $[3,8]$. In contrast, false positives may arise due to two problems associated with RT-qPCR: contamination and determination of the limit at which it may be affirmed that a sample with a low viral load is in fact positive [9]. Notably, a positive molecular test indicates only the detection of viral RNA and may be unrelated to the presence of infectious virus [8].

In addition to methodological aspects, it should be stressed that a different SARS-CoV-2 level may be the result of different tissue expression of the receptors with which the virus interacts-angiotensin-converting enzyme 2 (ACE2) and transmembrane protease serine 2 (TMPRSS2)—suggesting possible routes of infection other than respiratory droplets. For this reason, research efforts have to date focused on various objectives, including the study of the routes of viral transmission and the research and validation of diagnostic methods.

The impact of SARS-CoV-2 on male reproduction has not yet been established. An important aspect for reproductive medicine is whether or not this virus is found in seminal fluid. While a number of recent literature studies have investigated the presence of SARS-CoV-2 in semen, only one reported positive results, in four acute and two recovering COVID-19 patients (19\%) [10]. However, this study may have several major methodological limitations [11].

The identification of SARS-CoV-2 in different clinical samples using RT-PCR is not yet well established. For this reason, the aim of our study was to verify RT-PCR in semen samples, to establish if SARS-CoV-2 is truly found in semen and if this can be used for diagnosis.

\section{Materials and methods}

\section{Patients}

Patients from the Infectious Disease Department of the Policlinico Umberto I Hospital_-"Sapienza" University of Rome were asked to provide a semen sample for viral RNA determination. They comprised:

- Mild COVID-19 patients with a recent nasopharyngeal swab positive for SARS-CoV-2 ( $\mathrm{pt} \# 1$ and $\mathrm{pt} \# 2$ ).

- Recovered COVID-19 patients with a recent nasopharyngeal swab negative for SARS-CoV-2 (pt \#3 and pt \#4).

Controls were recruited from healthy men attending the Laboratory of Seminology_Sperm Bank "Loredana Gandini" who were performing semen analysis as a part of pre-conceptional screening and had had a negative nasopharyngeal swab for SARS-CoV-2. All patients provided their written informed consent before any study procedures were carried out. This study was approved by our institution's Ethics Committee (Ref. 5971, protocol 0646/2020).

\section{Semen analysis}

Semen samples were collected by masturbation into a sterile plastic container. Given the patients' medical condition, days of abstinence were not taken into consideration. All samples were allowed to liquefy at $37{ }^{\circ} \mathrm{C}$ for $60 \mathrm{~min}$ and were then assessed according to World Health Organization guidelines (2010). The following variables were assessed: ejaculate volume $(\mathrm{ml})$, sperm concentration $\left(n \times 10^{6} / \mathrm{ml}\right)$, total sperm number $\left(n \times 10^{6} /\right.$ ejaculate $)$, progressive motility (\%) and morphology (\% abnormal forms). A sperm viability test was carried out to differentiate cell death from immotility by staining with eosin $\mathrm{Y}$ $0.5 \%$ in saline solution.

\section{Processing of semen samples}

To evaluate the possible presence of SARS-CoV-2 in different fractions of seminal fluid, each sample was processed as follows (Fig. 1):

- $140 \mu$ l of whole seminal fluid was used to extract Viral RNA.

- An aliquot of seminal fluid was centrifuged at $3000 \mathrm{rpm}$ for $10 \mathrm{~min}$ to separate seminal plasma from spermatozoa and other cellular elements. The pellet containing spermatozoa, leukocytes and epithelial cells was diluted with $0.5 \%$ saline (cell suspension). 
- $140 \mu \mathrm{l}$ of seminal plasma and $140 \mu \mathrm{l}$ of cell suspension were used to extract viral RNA.

\section{Detection of SARS-CoV-2 RNA in semen}

Viral RNA from $140 \mu$ of whole seminal fluid, and seminal plasma was extracted using QIAamp viral RNA kit (Qiagen) according to the manufacturer's instructions. Six $\mu$ of a heterologous amplification system (Internal Control-RealStar SARS-CoV2 RT PCR, Altona Diagnostics) was used as control for extraction procedure and RT-PCR inhibition. Total RNA extraction from cell suspension was performed using Norgen total RNA purification kit (Norgen Biotek Corporation) according to the manufacturer's instructions. Ten $\mu \mathrm{l}$ of extracted RNA was reverse-transcribed and simultaneously amplified using a real-time RT-PCR system (RealStar
SARS-CoV2 RT PCR, Altona Diagnostics) targeting E and $S$ viral genes. PRM1 and PRM2 mRNA, sperm-specific nuclear proteins, was used as the control for sperm RNA extraction, using RT-PCR (TaqMan ${ }^{\mathrm{TM}}$ Gene Expression Assay, Applied Biosystems).

\section{Control panel}

To assess whether viral RNA extraction was affected by the use of whole seminal fluid, a known titer of SARS-CoV-2 virus was added to semen from a healthy donor. The panel was prepared with serial dilutions of a SARS-CoV-2 isolate (named 2019-nCoV/Italy-INMI1) [12]. The virus was collected by nasopharyngeal swab and cultured in Vero E6 cell lines grown in MEM containing 2\% FBS. The dilutions ranged from $4 \times 10^{2}$ to $4 \times 10^{6}$ viral RNA copies $/ \mathrm{ml}$,

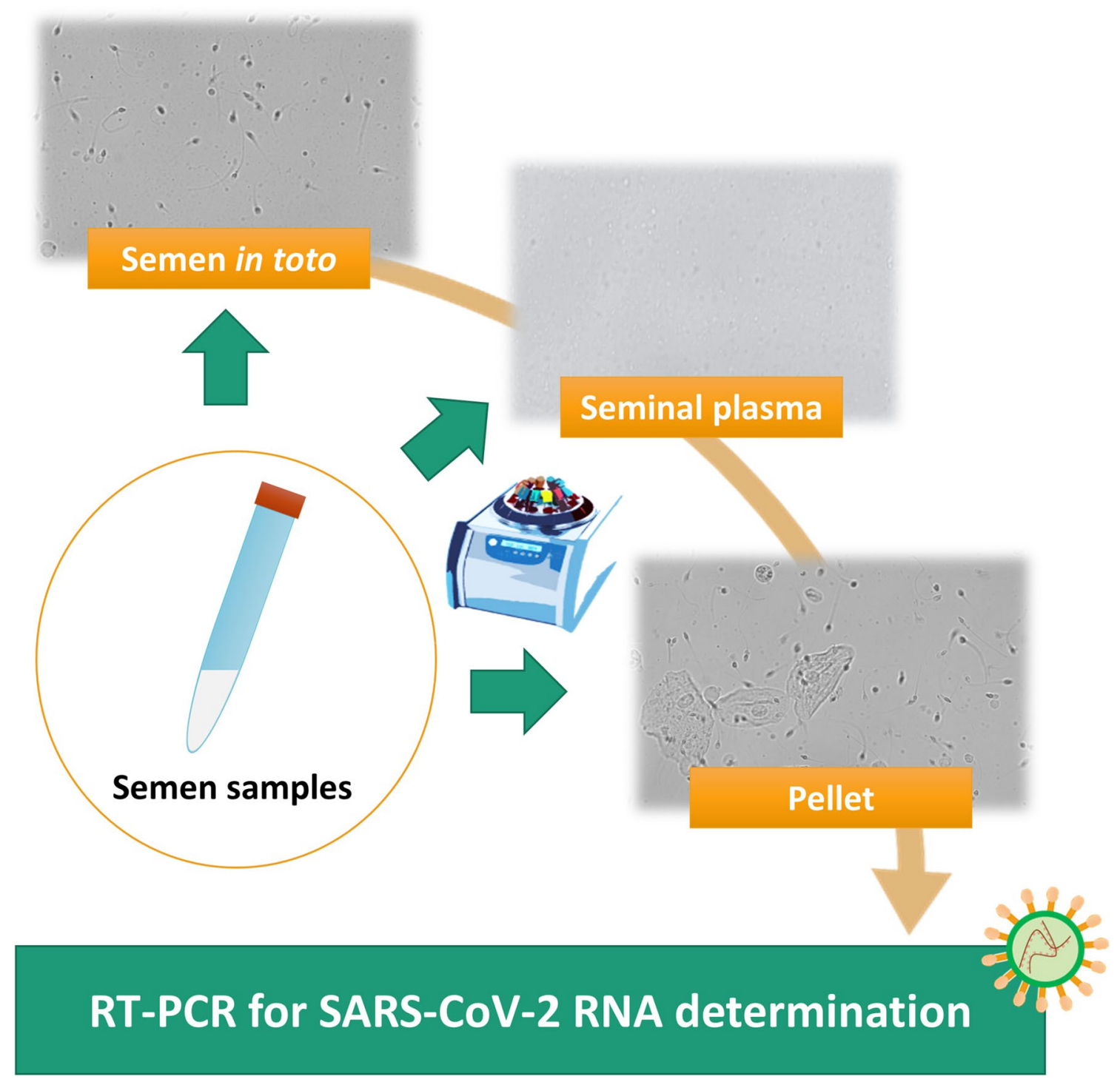

Fig. 1 Schematic representation of semen samples processing 
corresponding to 0.1 and 1000 TCID50 (50\% tissue culture infective dose)/ml. SARS-CoV-2 RNA was amplified by qRT-PCR and quantified based on a standard curve prepared through serial dilutions of EURM-019 single-stranded RNA (ssRNA) fragments of SARS-CoV-2 including different target genes (https://crm.jrc.ec.europa.eu/p/EURM-019). Viral titers were determined by limiting dilution assay on Vero E6 cells and infectivity was expressed as TCID50/ml, calculated according to the Reed and Muench method. A blank containing only cell culture medium was included in the panel. Two known titer viral preparations from the panel were diluted $1: 2$ in seminal fluid and in $0.5 \%$ saline solution (Fig. 2). The final concentrations of the tested samples were $2 \times 10^{4}$ and $2 \times 10^{6}$ copies $/ \mathrm{ml}$.

\section{Results}

Patient information is summarized in Fig. 3 and Table 1. The semen sample after a positive nasopharyngeal test was obtained from $\mathrm{pt} \# 1$ on the same day of the positive nasopharyngeal swab was performed, and from pt \#2 within $48 \mathrm{~h}$ of the last positive swab. All tested semen samples (both COVID-19 patients and controls) were negative for SARSCoV-2 RNA, regardless of the nasopharyngeal swab result. To investigate the presence of the virus in different fractions of seminal fluid, we also extracted RNA from whole samples, seminal plasma and post-centrifugation pellets containing only the corpuscular part of the seminal fluid, namely spermatozoa, germ cells, leukocytes and epithelial cells. We did not detect the virus in any of these fractions. Internal control was detected in all samples. Semen parameters of all recruited subjects are shown in Table 2 .

\section{RNA extraction}

To verify the efficiency of RNA extraction from sperm we used PRM1 and PRM2 mRNA as the control. Protamines 1 or 2 are the most abundant and specific nuclear proteins in human sperm [13]. PRM1 and PRM2 mRNA expression was found in all the semen samples (data not shown), demonstrating a good extraction capacity from this matrix.

\section{Control panel}

The assays were evaluated against a panel using negative control samples and $0.5 \%$ saline solution. We tested diluted controls infected with a known titer of SARS-CoV-2 virus. This was required to assess if any substances in the seminal fluid might interfere with viral RNA extraction, inducing false negatives or false positives. Two known titer viral preparations from a panel were diluted 1:2 in seminal fluid (from SARS COV2-negative patients) and in 0.5\% saline solution. All samples obtained by diluting viral preparation from the panel tested positive for SARS-CoV-2, with no RT-PCR inhibition detected.

The final virus concentrations were $2 \times 10^{4}$ and $2 \times 10^{6}$ copies $/ \mathrm{ml}$. Viral preparations diluted in saline and seminal

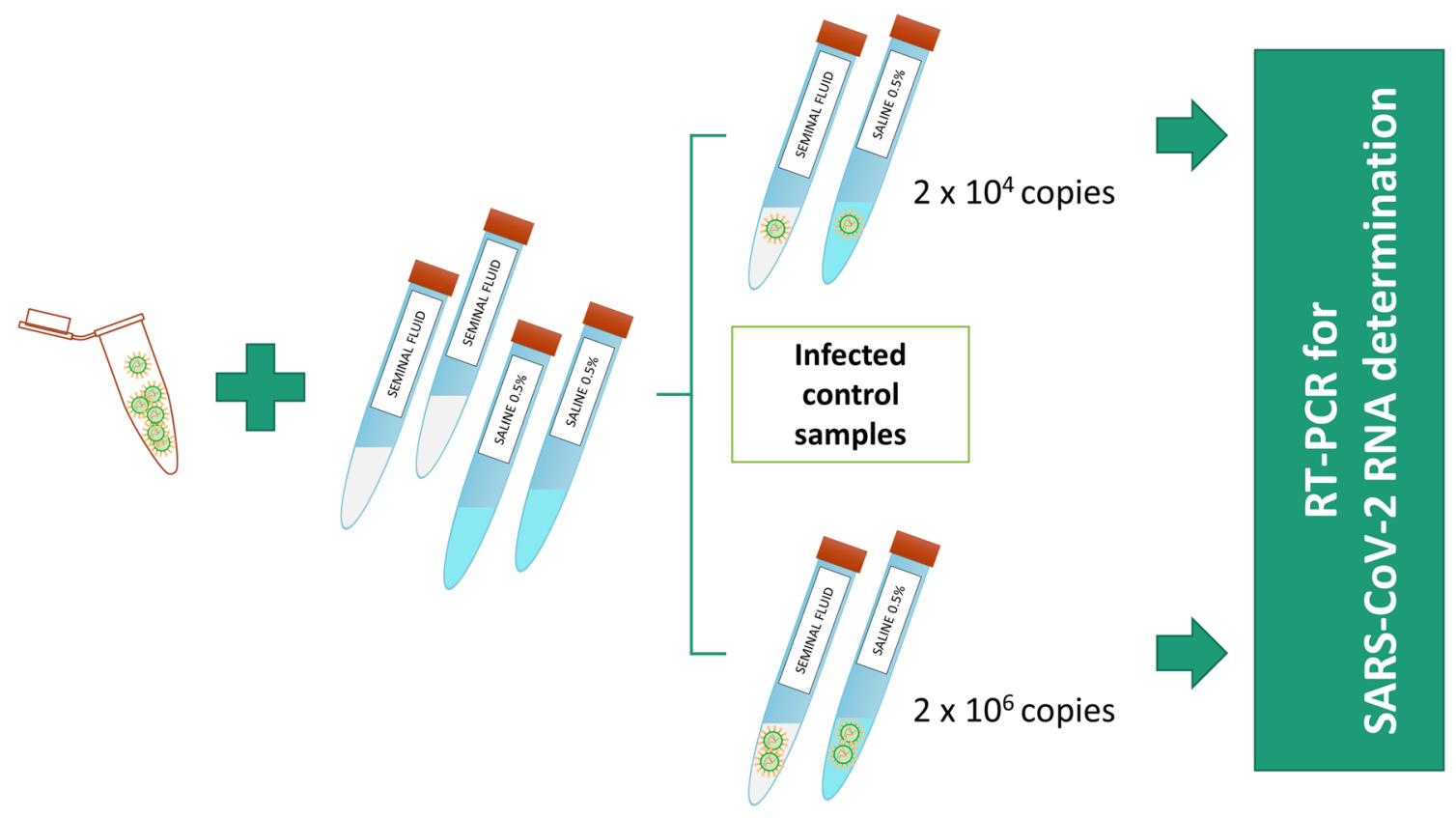

Fig. 2 Preparations of control panel samples diluted in seminal fluid and in $0.5 \%$ saline solution 


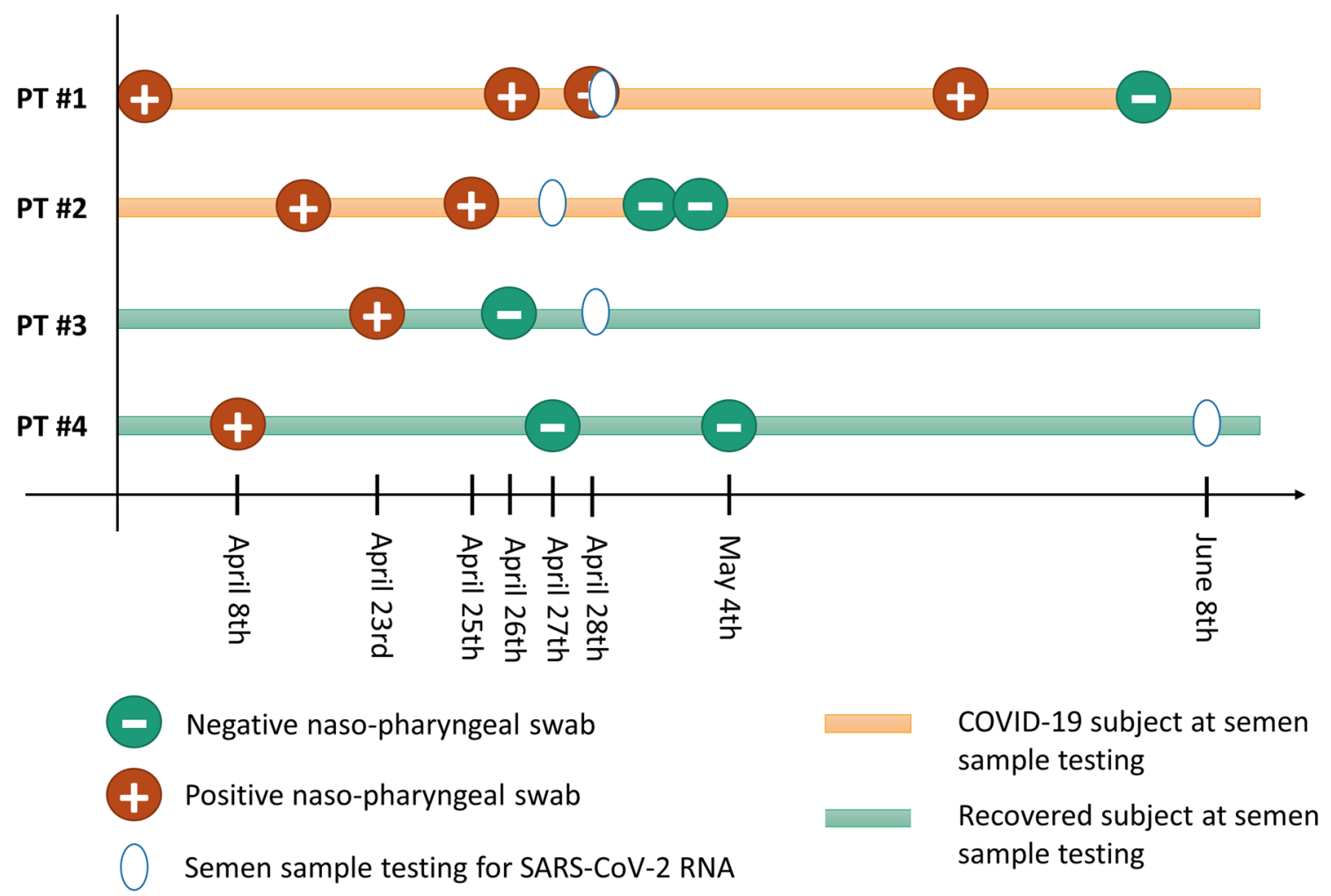

Fig. 3 Patient's information

fluid showed a similar Ct value to the initial viral concentration, as shown in Table 3.

\section{Discussion}

The outbreak of coronavirus disease (COVID-19) caused by SARS-CoV-2 has raised a number of concerns about public health, including sex-related mortality $[14,15]$. Epidemiological studies suggested that males are more likely to test positive for COVID-19 [16]. This has prompted questions about the possible repercussions of SARS-CoV-2 for the male reproductive system. SARS-CoV-2 enters cells by means of a viral receptor, angiotensin-converting enzyme 2 (ACE2), which is highly expressed in a wide range of human tissues. In the testis, ACE2 expression has been found on seminiferous duct cells, spermatogonia, and Leydig and Sertoli cells, confirming the potential risks to the reproductive system associated with SARS-CoV-2 infection [17]. SARS-CoV-2 also requires transmembrane protease serine 2 (TMPRSS2) to enter cells. This proteolytic enzyme is involved in numerous physiological processes [18]. TMPRSS2 cleaves and modifies spike protein, enabling the permanent fusion of the virus and host cell [19]. It is highly expressed in the prostate epithelial cells, and its expression is regulated by androgens. The question thus arises: can SARS-CoV-2 reach the seminal fluid?

Several authors have investigated the presence of SARSCoV-2 in semen [10, 20-32] (Table 4). They all conducted a search for viral RNA through RT-PCR, albeit screening for different genes. It must be stressed that of the 15 publications to date that have investigated this aspect, only 1 reported finding viral RNA in semen from both acute (26.7\%) and recovering (8.7\%) patients [10]. Furthermore, SARS-CoV-2 has currently only been investigated in semen in 31 acute COVID-19 cases and relatively few recovering subjects, including the aforementioned study. Overall, only 4 acute and 3 recovered patients have been reported to have seminal fluid positive for viral RNA over a total of 341 subjects evaluated (Table 4). Since most positive subjects came from the same study, the peculiar clinical conditions (disease severity) and methodological weaknesses of this paper have been discussed [11]. Recently, another paper reported a SARS-CoV-2-positive seminal fluid in a caseload of 15 mild-asymptomatic subjects, however, the presented data are scant [33]. However, further factors influencing the heterogeneity of these papers should also be recognized, including different ethnicities, slightly different definitions for acute cases, and huge differences in timing for the testing of recovering cases. On the hypothesis that the virus sheds into semen, all these factors could greatly affect both viral 


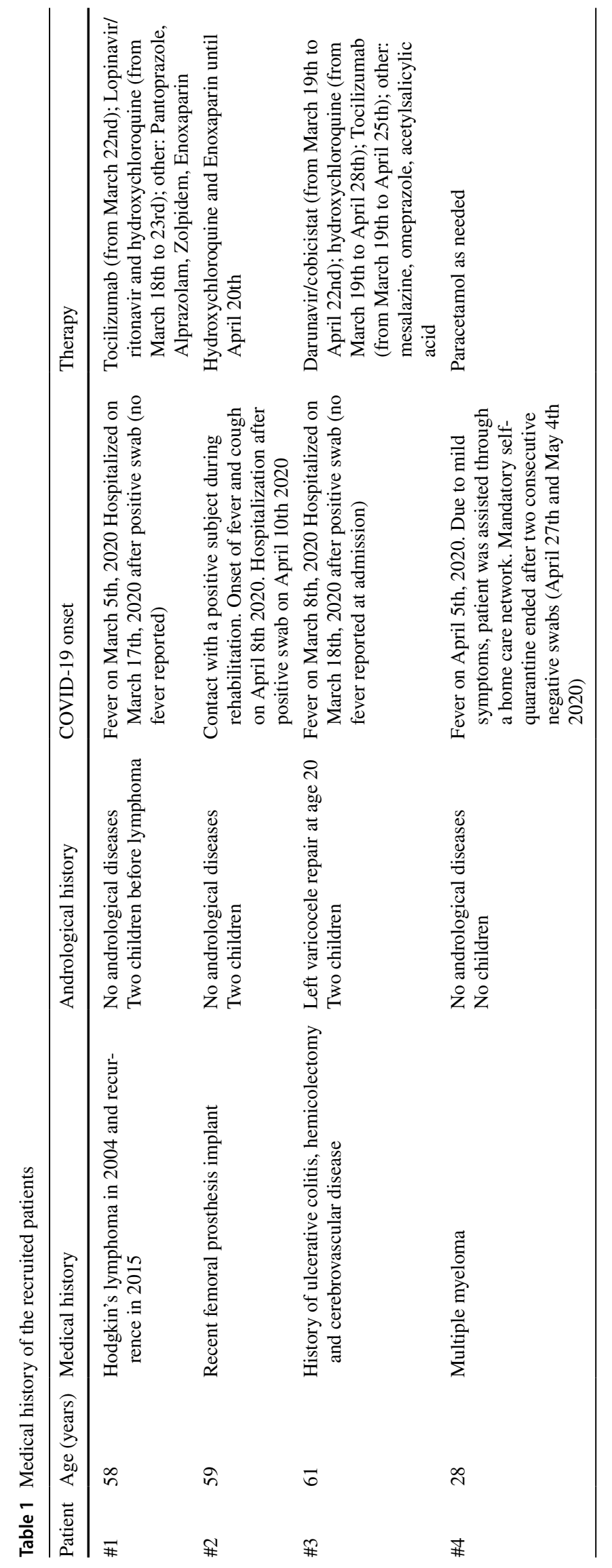




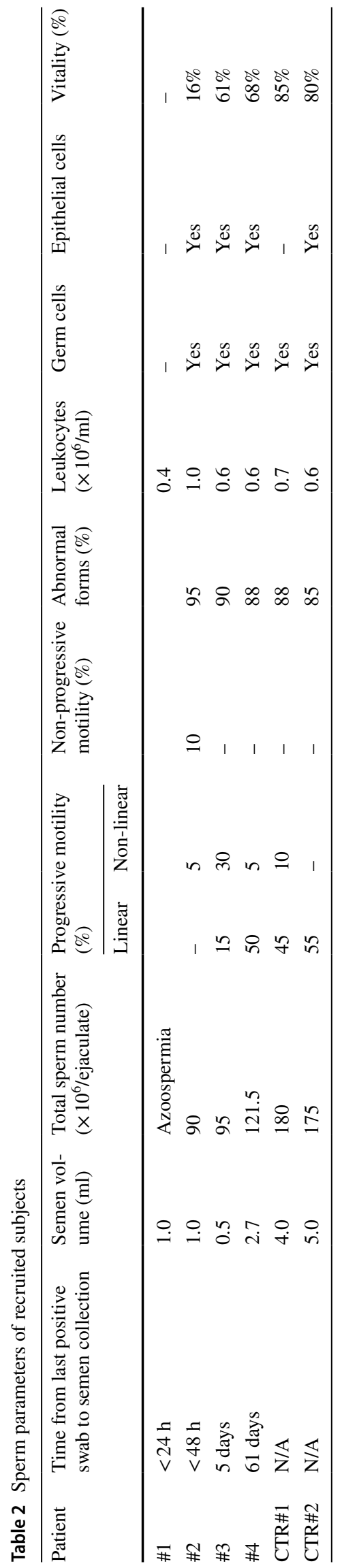

load and viral clearance in semen, and hence the chance of its detection. Consequently, although the presence of SARS-CoV-2 in semen cannot yet be completely excluded, the available data may be interpreted cautiously, but optimistically - especially given the absence of solid proof of its presence in the testes of non-severe COVID-19 cases [34].

Gonzales et al. [35] reviewed literature data on the presence of SARS-CoV-2 in semen. They found a very low risk in seminal fluid, and a negligible risk in recovered men [35]. These results suggest that the likely absence of SARSCoV-2 in seminal fluid may be influenced by biological or methodological factors. In relation to biological factors, we know that the testicles may be vulnerable to SARS-CoV-2 infection. However, given the concentration of SARS-CoV-2 receptors present in testicular tissue, why is the infection not clinically evident in the testes [36]? Studies based on single-cell RNA sequencing (sc RNAseq) in humans did not find any ACE2/TMPRSS2 co-expression in any type of testicular tissue [37]. In theory, viruses could reach semen from the blood, as the blood-testis barrier does not seem to constitute an insurmountable obstacle to viruses in the presence of systemic or local inflammation [38]. To date, few studies have investigated the presence of SARS-CoV-2 in blood. Bwire et al. reported a low (1.0\%) detection of SARS-CoV-2 in blood samples [6]. It could be that the virus only spreads to blood under certain circumstances, such as the acute phase or severe disease, and then to other organs such as the testis [39].

Methodological factors are also important. While qRTPCR assay, as discussed above, is the first-line screening method of choice for SARS-CoV-2 detection due to its high sensitivity and rapid detection [7], there is a real risk of false negative and false positive results [40]. False negative results may be due to sample inhibitors, poor amplification efficiency, and reduced precision in low concentration samples. False positives could arise from contaminants or poor test specificity [41]. In any case, the sensitivity and specificity of the RT-PCR methods used to detect SARS-CoV-2 in seminal fluid have not been evaluated [42].

In our study, we investigated the presence of SARSCOV-2 in seminal fluid from four COVID-19 patients: two mild cases with a positive recent nasopharyngeal swab and two whose last swab was negative. We did not find SARSCoV-2 RNA in any of these samples. Semen analyses from the positive patients showed some abnormalities; specifically, patient \#1 was azoospermic and patient \#2 asthenozoospermic. It should be stressed that these semen characteristics are likely to be due to their medical history: patient \#1 had undergone chemotherapy for lymphoma, while the asthenozoospermia of patient \#2 was probably caused by his clinical condition, its treatment, and prolonged abstinence.

For a qualitative determination of the RT-PCR assays in semen we performed different attempts: (1) we verified 
Table 3 RT-PCR Ct values for $\mathrm{S}$ and $\mathrm{E}$ genes detected in control samples of whole seminal fluid and $0.5 \%$ saline solution infected with known titers of SARS-CoV-2

\begin{tabular}{lll}
\hline SPECIMEN & Ct S gene & Ct E gene \\
\hline SARS-CoV-2 in seminal fluid $\left(4 \times 10^{4}\right.$ copies $/ \mathrm{ml}$; diluted 1:2) & 31.7 & 33.4 \\
SARS-CoV-2 in saline $\left(4 \times 10^{4}\right.$ copies $/ \mathrm{ml}$; diluted 1:2) & 31.9 & 32.8 \\
SARS-CoV-2 in seminal fluid $\left(4 \times 10^{6}\right.$ copies $/ \mathrm{ml}$; diluted 1:2) & 25.8 & 26.8 \\
SARS-CoV-2 in saline $\left(4 \times 10^{6}\right.$ copies $/ \mathrm{ml}$; diluted 1:2) & 25.0 & 25.9
\end{tabular}

Table 4 Summary of relevant literature evidence available on SARS-CoV-2 RNA detection in seminal fluid

\begin{tabular}{|c|c|c|c|c|c|c|c|}
\hline References & Total Patients & $\begin{array}{l}\text { Age (mean or } \\
\text { range) }\end{array}$ & $\begin{array}{l}\text { Acute (positive } \\
\text { semen) }\end{array}$ & $\begin{array}{l}\text { Acute (negative } \\
\text { semen) }\end{array}$ & $\begin{array}{l}\text { Recovered (posi- } \\
\text { tive semen) }\end{array}$ & $\begin{array}{l}\text { Recovered (nega- } \\
\text { tive semen) }\end{array}$ & Method \\
\hline Gacci et al. [20] & 43 & $30-64$ & & & 1 & 42 & RT-PCR \\
\hline Li et al. [21] & 23 & 69.3 & & & 0 & 23 & RT-PCR \\
\hline Ruan et al. [22] & 70 & 30.5 & & & 0 & 70 & RT-PCR \\
\hline Temiz et al. [26] & 30 & 37.2 & & & 0 & 30 & RT-PCR \\
\hline Rawlings et al. [27] & 6 & 38 & & & 0 & 6 & RT-PCR \\
\hline Pavone et al. [28] & 9 & 42 & & & 0 & 9 & RT-PCR \\
\hline Kayaaslan et al. [29] & 16 & 33.5 & 0 & 10 & 0 & 6 & RT-PCR \\
\hline Holtmann et al. [30] & 20 & 42.2 & 0 & 2 & 0 & 18 & RT-PCR \\
\hline Ma et al. [23] & 12 & 31.5 & 0 & 1 & 0 & 11 & RT-PCR \\
\hline Guo et al. [24] & 23 & 41 & & & 0 & 23 & RT-PCR \\
\hline Pan et al. [25] & 34 & 37 & & & 0 & 34 & RT-PCR \\
\hline Li et al. [10] & 38 & $\mathrm{n} / \mathrm{a}$ & 4 & 11 & 2 & 21 & RT-PCR \\
\hline Paoli et al. [32] & 1 & 32 & & & 0 & 1 & RT-PCR \\
\hline Song et al. [31] & 12 & $22-38$ & 0 & 1 & 0 & 11 & RT-PCR \\
\hline Present study & 4 & 51.5 & 0 & 2 & 0 & 2 & RT-PCR \\
\hline Total & 341 & & 4 & 27 & 3 & 307 & \\
\hline
\end{tabular}

the efficiency of RNA extraction from sperm and seminal plasma using PRM1 and PRM2 mRNA and a heterologous system, respectively, as control; (2) we tested samples obtained by diluting viral preparation from a panel tested positive for SARS-CoV-2, with no RT-PCR inhibition detected; (3) we investigated the presence of the virus in different fractions of seminal fluids, whole samples, seminal plasma and post-centrifugation pellets containing only the corpuscular part of the seminal fluid. We did not detect the virus in any of these fractions.

Our study not only demonstrated the absence of SARS COV2 in the seminal fluid of patients in the acute phase with a positive nasopharyngeal swab and in recovered patients with a negative swab, but for the first time confirmed the feasibility of this test for the molecular diagnosis of SARS-CoV-2 in seminal fluid. This result is important in two ways. First, it confirms the literature data on the absence of the virus in seminal fluid in patients with mild COVID-19, and second, it verifies the molecular method used through various tests. This information is important for reproductive medicine, especially in assisted reproductive technology and sperm cryopreservation.
The limitation of this method in relation to seminal fluid is that contamination could lead to a false positive. It should be stressed that semen collection is not sterile, and the sample could be contaminated with respiratory droplets or other body fluids from the patient, or by the patient's hands. For this reason, any positive test result should be confirmed by repeating the test, alongside an evaluation of the patient's symptoms and a thorough andrological history.

In our opinion, the molecular diagnosis of SARS COV2 in seminal fluid could be a useful tool for specialists in reproductive medicine to evaluate the safety of sperm.

Author contributions DP, OT and FL conceived and designed the experiments; DP and FP wrote the article; OT, MBV, LM, DP acquired virological and seminal data; GN, MH, SC recruited patients; FP and GN analyzed clinical data; CMM, GA, AL, FL contributed to manuscript revision.

Funding Open access funding provided by Università degli Studi di Roma La Sapienza within the CRUI-CARE Agreement. None.

Availability of data and materials Not applicable. 
Code availability Not applicable.

\section{Declarations}

Conflict of interest All the authors declare that they have no conflict of interest.

Ethics approval This study was approved by our institutional ethics committee: Ethics Committee "Sapienza" (Ref. 5971, protocol 0646/2020).

Research involving human participants All procedures performed in this study involving human participants were in accordance with the ethical standards of the institutional research committee and with the 1964 Helsinki Declaration and its later amendments or comparable ethical standards.

Informed consent All patients provided their written informed consent before any study procedures were carried out.

Open Access This article is licensed under a Creative Commons Attribution 4.0 International License, which permits use, sharing, adaptation, distribution and reproduction in any medium or format, as long as you give appropriate credit to the original author(s) and the source, provide a link to the Creative Commons licence, and indicate if changes were made. The images or other third party material in this article are included in the article's Creative Commons licence, unless indicated otherwise in a credit line to the material. If material is not included in the article's Creative Commons licence and your intended use is not permitted by statutory regulation or exceeds the permitted use, you will need to obtain permission directly from the copyright holder. To view a copy of this licence, visit http://creativecommons.org/licenses/by/4.0/.

\section{References}

1. Pascolo L, Zito G, Zupin L et al (2020) Renin angiotensin system, COVID-19 and male fertility: any risk for conceiving? Microorganisms 8(10):1492. https://doi.org/10.3390/micro organisms8101492

2. Lu R, Zhao X, Li J et al (2020) Genomic characterisation and epidemiology of 2019 novel coronavirus: implications for virus origins and receptor binding. Lancet 395:565-574. https://doi. org/10.1016/S0140-6736(20)30251-8

3. Lai CKC, Lam W (2020) Laboratory testing for the diagnosis of COVID-19. Biochem Biophys Res Commun. https://doi.org/ 10.1016/j.bbrc.2020.10.069

4. Wang W, Xu Y, Gao R et al (2020) Detection of SARS-CoV-2 in different types of clinical specimens. JAMA 323:1843-1844. https://doi.org/10.1001/jama.2020.3786

5. Jin X-D, Li Y, Song Y-S et al (2020) Progress in research on the detection of the novel coronavirus in human samples of different groups. Eur Rev Med Pharmacol Sci 24:10879-10884. https:// doi.org/10.26355/eurrev_202010_23452

6. Bwire GM, Majigo MV, Njiro BJ, Mawazo A (2021) Detection profile of SARS-CoV-2 using RT-PCR in different types of clinical specimens: a systematic review and meta-analysis. J Med Virol 93:719-725. https://doi.org/10.1002/jmv.26349

7. Machado BAS, Hodel KVS, Barbosa-Júnior VG et al (2020) The main molecular and serological methods for diagnosing COVID-19: an overview based on the literature. Viruses 13:40. https://doi.org/10.3390/v13010040
8. Riva E, Sainaghi PP, Turriziani O et al (2020) SARS-CoV-2 infection: diagnostic testing results occasionally require special attention. Emerg Microbes Infect 9:1955-1957. https://doi.org/ 10.1080/22221751.2020.1814165

9. Braunstein GD, Schwartz L, Hymel P, Fielding J (2021) False positive results with SARS-CoV-2 RT-PCR tests and how to evaluate a RT-PCR-positive test for the possibility of a false positive result. J Occup Environ Med. https://doi.org/10.1097/ JOM.0000000000002138 (Publish Ahead of Print)

10. Li D, Jin M, Bao P et al (2020) Clinical characteristics and results of semen tests among men with coronavirus disease 2019. JAMA Netw Open 3:e208292. https://doi.org/10.1001/ jamanetworkopen.2020.8292

11. Paoli D, Pallotti F, Turriziani O et al (2021) SARS-CoV-2 presence in seminal fluid: myth or reality. Andrology 9:23-26. https://doi.org/10.1111/andr.12825

12. Capobianchi MR, Rueca M, Messina F et al (2020) Molecular characterization of SARS-CoV-2 from the first case of COVID19 in Italy. Clin Microbiol Infect 26:954-956. https://doi.org/ 10.1016/j.cmi.2020.03.025

13. Grassetti D, Paoli D, Gallo M et al (2012) Protamine-1 and -2 polymorphisms and gene expression in male infertility: an Italian study. J Endocrinol Invest 35:882-888. https://doi.org/10. $3275 / 8111$

14. Foresta C, Rocca MS, Di Nisio A (2020) Gender susceptibility to COVID-19: a review of the putative role of sex hormones and $\mathrm{X}$ chromosome. J Endocrinol Invest. https://doi.org/10.1007/ s40618-020-01383-6

15. Wang F, Cao J, Yu Y et al (2021) Epidemiological characteristics of patients with severe COVID-19 infection in Wuhan, China: evidence from a retrospective observational study. Int J Epidemiol 49:1940-1950. https://doi.org/10.1093/ije/dyaa180

16. Vahidy FS, Pan AP, Ahnstedt $\mathrm{H}$ et al (2021) Sex differences in susceptibility, severity, and outcomes of coronavirus disease 2019: cross-sectional analysis from a diverse US metropolitan area. PLoS ONE 16:e0245556. https://doi.org/10.1371/journal. pone. 0245556

17. Corona G, Baldi E, Isidori AM et al (2020) SARS-CoV-2 infection, male fertility and sperm cryopreservation: a position statement of the Italian Society of Andrology and Sexual Medicine (SIAMS) (Società Italiana di Andrologia e Medicina della Sessualità). J Endocrinol Invest 43:1153-1157. https://doi.org/10. 1007/s40618-020-01290-w

18. Pascolo L, Zupin L, Melato M et al (2020) TMPRSS2 and ACE2 coexpression in SARS-CoV-2 salivary glands infection. J Dent Res 99:1120-1121

19. Sharma I, Kumari P, Sharma A, Saha SC (2021) SARS-CoV-2 and the reproductive system: known and the unknown...! Middle East Fertil Soc J 26:1. https://doi.org/10.1186/s43043-020-00046-z

20. Gacci M, Coppi M, Baldi E et al (2021) Semen impairment and occurrence of SARS-CoV-2 virus in semen after recovery from COVID-19. Hum Reprod. https://doi.org/10.1093/humrep/deab026

21. Li H, Xiao X, Zhang J et al (2020) Impaired spermatogenesis in COVID-19 patients. EClinicalMedicine 28:100604. https://doi. org/10.1016/j.eclinm.2020.100604

22. Ruan Y, Hu B, Liu Z et al (2021) No detection of SARS-CoV-2 from urine, expressed prostatic secretions, and semen in 74 recovered COVID-19 male patients: a perspective and urogenital evaluation. Andrology 9:99-106. https://doi.org/10.1111/andr.12939

23. Ma L, Xie W, Li D et al (2020) Evaluation of sex-related hormones and semen characteristics in reproductive-aged male COVID-19 patients. J Med Virol. https://doi.org/10.1002/jmv. 26259

24. Guo L, Zhao S, Li W et al (2021) Absence of SARS-CoV-2 in semen of a COVID-19 patient cohort. Andrology 9:42-47. https:// doi.org/10.1111/andr.12848 
25. Pan F, Xiao X, Guo J et al (2020) No evidence of severe acute respiratory syndrome-coronavirus 2 in semen of males recovering from coronavirus disease 2019. Fertil Steril 113:1135-1139. https://doi.org/10.1016/j.fertnstert.2020.04.024

26. Temiz MZ, Dincer MM, Hacibey I et al (2020) Investigation of SARS-CoV-2 in semen samples and the effects of COVID19 on male sexual health by using semen analysis and serum male hormone profile: a cross-sectional, pilot study. Andrologia 53:e13912. https://doi.org/10.1111/and.13912

27. Rawlings SA, Ignacio C, Porrachia M et al (2020) No evidence of SARS-CoV-2 seminal shedding despite SARS-CoV-2 persistence in the upper respiratory tract. Open Forum Infect Dis 7:ofaa325. https://doi.org/10.1093/ofid/ofaa325

28. Pavone C, Giammanco GM, Baiamonte D et al (2020) Italian males recovering from mild COVID-19 show no evidence of SARS-CoV-2 in semen despite prolonged nasopharyngeal swab positivity. Int J Impot Res 32:560-562. https://doi.org/10.1038/ s41443-020-00344-0

29. Kayaaslan B, Korukluoglu G, Hasanoglu I et al (2020) Investigation of SARS-CoV-2 in semen of patients in the acute stage of COVID-19 infection. Urol Int 104:678-683. https://doi.org/10. $1159 / 000510531$

30. Holtmann N, Edimiris P, Andree M et al (2020) Assessment of SARS-CoV-2 in human semen-a cohort study. Fertil Steril 114:233-238. https://doi.org/10.1016/j.fertnstert.2020.05.028

31. Song C, Wang Y, Li W et al (2020) Absence of 2019 novel coronavirus in semen and testes of COVID-19 patients $\dagger$. Biol Reprod 103:4-6. https://doi.org/10.1093/biolre/ioaa050

32. Paoli D, Pallotti F, Colangelo S et al (2020) Study of SARS-CoV-2 in semen and urine samples of a volunteer with positive nasopharyngeal swab. J Endocrinol Invest 43:1819-1822. https://doi. org/10.1007/s40618-020-01261-1

33. Machado B, Barcelos Barra G, Scherzer N et al (2021) Presence of SARS-CoV-2 RNA in semen-cohort study in the United States COVID-19 positive patients. Infect Dis Rep 13:96-101. https:// doi.org/10.3390/idr13010012
34. Sansone A, Mollaioli D, Ciocca G et al (2021) Addressing male sexual and reproductive health in the wake of COVID-19 outbreak. J Endocrinol Invest 44:223-231. https://doi.org/10.1007/ s40618-020-01350-1

35. Gonzalez DC, Khodamoradi K, Pai R et al (2020) A systematic review on the investigation of SARS-CoV-2 in semen. Res Rep Urol 12:615-621. https://doi.org/10.2147/RRU.S277679

36. Groner MF, de Carvalho RC, Camillo J et al (2021) Effects of Covid-19 on male reproductive system. Int Braz J Urol 47:185190. https://doi.org/10.1590/S1677-5538.IBJU.2021.99.04

37. Stanley KE, Thomas E, Leaver M, Wells D (2020) Coronavirus disease-19 and fertility: viral host entry protein expression in male and female reproductive tissues. Fertil Steril 114:33-43. https:// doi.org/10.1016/j.fertnstert.2020.05.001

38. Khan RIN, Malla WA (2020) Does SARS-CoV-2 have influence on male reproductive system? Hum Reprod 35:2626-2627. https:// doi.org/10.1093/humrep/deaa239

39. Paoli D, Pallotti F, Nigro G et al (2020) Sperm cryopreservation during the SARS-CoV-2 pandemic. J Endocrinol Invest. https:// doi.org/10.1007/s40618-020-01438-8

40. Tahamtan A, Ardebili A (2020) Real-time RT-PCR in COVID19 detection: issues affecting the results. Expert Rev Mol Diagn 20:453-454. https://doi.org/10.1080/14737159.2020.1757437

41. Falasca F, Sciandra I, Di Carlo D et al (2020) Detection of SARSCOV N2 gene: very low amounts of viral RNA or false positive? J Clin Virol 133:104660. https://doi.org/10.1016/j.jcv.2020.104660

42. Madjunkov M, Dviri M, Librach C (2020) A comprehensive review of the impact of COVID-19 on human reproductive biology, assisted reproduction care and pregnancy: a Canadian perspective. J Ovar Res 13:140. https://doi.org/10.1186/ s13048-020-00737-1

Publisher's Note Springer Nature remains neutral with regard to jurisdictional claims in published maps and institutional affiliations.

\section{Authors and Affiliations}

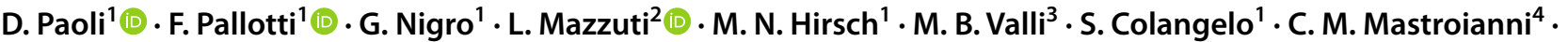 G. Antonelli ${ }^{2} \cdot$ A. Lenzi ${ }^{1}(1) \cdot$ O. Turriziani ${ }^{2} \oplus \cdot$ F. Lombardo $^{1}(\mathbb{1}$}

F. Pallotti

francesco.pallotti@uniroma1.it

G. Nigro

giulia.nigro@uniroma1.it

L. Mazzuti

laura.mazzuti@uniroma1.it

M. N. Hirsch

marianeve.hirsch@uniroma1.it

M. B. Valli

mariabeatrice.valli@inmi.it

S. Colangelo

stefano.colangelo03@gmail.com

C. M. Mastroianni

claudio.mastroianni@uniroma1.it

G. Antonelli

guido.antonelli@uniroma1.it

A. Lenzi

andrea.lenzi@uniroma1.it
O. Turriziani

ombretta.turriziani@uniroma1.it

F. Lombardo

francesco.lombardo@uniroma1.it

1 Laboratory of Seminology-Sperm Bank "Loredana Gandini”, Department of Experimental Medicine,

"Sapienza" University of Rome, Viale del Policlinico 155, 00161 Rome, Italy

2 Laboratory of Virology, Department of Molecular Medicine, "Sapienza" University of Rome, Rome, Italy

3 National Institute for Infectious Diseases, INMI (Istituto Nazionale Per Le Malattie Infettive), "Lazzaro Spallanzani" IRCCS, Rome, Italy

4 Department of Public Health and Infectious Diseases, "Sapienza" University of Rome, Rome, Italy 